\title{
INFLUENCE OF QUANTITIES OF BREWER YEAST ON THE PERFORMANCE OF ANASTREPHA OBLIQUA WILD FEMALES (DIPTERA, TEPHRITIDAE)
}

\author{
Carla Cresoni-Pereira ${ }^{1}$ \\ Fernando Sérgio Zucoloto ${ }^{1}$
}

\begin{abstract}
Using artificial solid diets, experiments were performed with Anastrepha obliqua (Macquart, 1835) wild females in order to verify the influence of different quantities of brewer yeast on the performance and compensation behavior to unbalanced diets ingestion. The observed parameters were egg production, ingestion, diet efficiency and survival in the reproductive phase. Results indicated that there was no compensatory ingestion to different quantities of yeast and that the diet with $12.5 \mathrm{~g}$ of yeast provided the best performance. The absence of compensatory ingestion is discussed based on the yeast phagostimulation and on the costs involved in solid diets ingestion. The relation between the analyzed parameters and the protein quantities in the diet were discussed.
\end{abstract}

KEYWORDS. Protein, feeding, West Indian, fruit fly.

\section{INTRODUCTION}

The fruit flies, before becoming sexually mature, pass by a maturation period during which they need to feed on carbohydrates and water to survive and on the protein source to mature their eggs (BRAGA \& Zucoloto, 1981; Aluja, 1994). They are anautogen insects because there is no egg production without protein ingestion in the adult phase. According to Cangussu \& ZuColoto (1992) in studies with medfly Ceratitis capitata (Wiedemann, 1824) fruitflies, using insects reared in laboratory on artificial diets, when a nutrient (protein in this case) is offered in different concentrations, the highest ingestion occurs when the concentration is small and therefore unsatisfactory to the organism needs. This compensatory response was already studied in other insects (SIMPSON \& Abisgold, 1985; Abisgold \& Simpson, 1987; Hamilton \& Schal, 1988; Simpson et al., 1989). Studies with Anastrepha suspensa (Loew, 1873) showed that compensatory responses did not occur to hydrolyzed yeast, but they did to carbohydrates (SHARP \& Chambers, 1984). Fontellas \& Zucoloto (1999) found that A. obliqua (Macquart, 1835) females also ingested in a compensatory way when they were fed on solutions with different concentrations of sucrose. The same did not occur when the females were fed on solid diets with different concentrations of sucrose.

Based on these data, the objective was to verify the optimal quantity of brewer yeast (protein source) to A. obliqua females in relation to performance, and whether these females show compensatory responses to the variation of the yeast quantities in the solid diet.

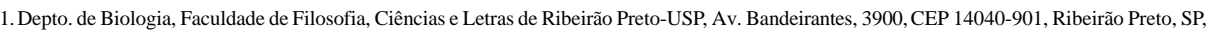
Brasil. 


\section{MATERIAL AND METHODS}

The females originated from a population collected from infested Spondias venulosa (Linnaeus) and $S$. purpurea (Linnaeus) fruits. Fruits were collected in the "Universidade de São Paulo campus" and "Fazenda Experimental do Instituto Agronômico de Campinas", both in Ribeirão Preto, SP, Brasil. The fruits were maintained in a plastic tray with sand, until their pulp dried. Then, the sand was sieved and the pupae collected and maintained in acrylic boxes with sterilized sand. The boxes with pupae and the experimental boxes were maintained in stove with constant temperature $\left(29 \pm 1^{\circ} \mathrm{C}\right)$ and humidity $(70 \pm 1 \%)$. After emergence, females were separated at random in boxes. Ten females were used by replication ( 1 box $=1$ replication) and the replication number varied with the experiment.

To all experiments daily ingestion measurements were done, according to CANGUSSU \& ZuCOLOTO (1995): two diet pieces of $400 \mathrm{mg}$ each were offered daily to the flies, and the same quantity was placed in a box containing no flies, to calculate evaporation. After 24 hours, the diets were transferred to stove at $80 \pm 1^{\circ} \mathrm{C}$ and left for 24 hours until they reached constant dry weight. Ingestion was calculated by the following formula: $\mathrm{I}=\mathrm{TDM}-\mathrm{RDM} / \mathrm{N} ; \mathrm{I}=$ ingestion, $\mathrm{TDM}=$ total dried mater, $\mathrm{RDM}=$ remaining dried mater, $\mathrm{N}=$ number of living flies.

Two kinds of diet were used: one with carbohydrate only (11.0g of sucrose, Mallinckrodt-USA), $3.0 \mathrm{~g}$ of agar (Difco), $100.0 \mathrm{ml}$ of distilled water and $1.5 \mathrm{ml}$ of Nipagin (alcoholic solution at $20 \%$ ). The protein diet had the same composition, but with yeast (Boneg) in variable quantities according to the experiment. The diets were prepared according to ZucoLoto et al. (1979).

The dead females were removed daily, counted and their eggs were also counted. The experiments were performed in 18 days (pre-oviposition phase). After 18 days, the females started laying eggs all over the box, making it impossible to count individual ovipositions. At the end of 18 days, the remaining females were killed by freezing and preserved in alcohol at $70 \%$ with glycerin. After a minimum time of 48 hours, the females were dissected and their eggs counted with the help of a magnifying glass (10X magnification).

The data were analyzed statistically by the SigmaStat for Windows program, 1994, by Jandel Corporation.

\section{RESULTS}

In the first experiment, 5 different quantities of yeast were tested: $0.0 \mathrm{~g}, 1.0 \mathrm{~g}$, $2.5 \mathrm{~g}, 4.5 \mathrm{~g}$ and $6.0 \mathrm{~g}$. For each amount, 3 replications were done ( 3 boxes). Results were analyzed using the Kruskal-Wallis test, at a significance level of $5 \%$.

The highest ingestion rate $(1.84 \mathrm{mg} / \mathrm{female} /$ day) occurred in the diet with highest protein amount ( $6.5 \mathrm{~g}$ yeast) (tab. I). Ingestion of the $4.5 \mathrm{~g}$ yeast diet did not show any statistical difference in relation to ingestion of the $6.5 \mathrm{~g}$ yeast diet, presenting a very close average $(1.72 \mathrm{mg} /$ female/day). Ingestion of no-yeast diets and of $1.0 \mathrm{~g}$ and $2.5 \mathrm{~g}$ yeast diets did not show any statistical difference among them, differing only from the 4.5 yeast diet and the $6.5 \mathrm{~g}$ yeast diet.

Concerning egg production (tab. I), the $6.5 \mathrm{~g}$ yeast diet also yielded the best results in absolute terms (1.00 egg/female/day). This result did not differ statistically from the one obtained in the $4.5 \mathrm{~g}$ yeast diet $(0.43 \mathrm{egg} / \mathrm{female} / \mathrm{day})$. Production in the other diets did not show any statistical difference.

In terms of diet efficiency, the diets containing $4.5 \mathrm{~g}$ and $6.5 \mathrm{~g}$ yeast were statistically identical; however, the $6.5 \mathrm{~g}$ yeast diet was superior than the other 3 diets. Survival did not differ statistically in any of the tested quantities (fig. 1).

Other yeast quantities were tested (experiment 2 ): $8.5 \mathrm{~g} ; 10.5 \mathrm{~g} ; 12.5 \mathrm{~g} ; 14.5 \mathrm{~g}$; $16.5 \mathrm{~g}$ and $18.5 \mathrm{~g}$. Groups were assembled and analyzed in pairs. This procedure was used because females were originated from different fruits from different periods. There are variations in the nutrient levels among different fruits from different periods. In groups assembled and analyzed in pairs the influence of these differences are not so important. Five replications were done for each group. Results were analyzed by the 
Table I. Performance in A. obliqua females fed on diets with different quantities of yeast, during 18 days. Each group consisted initially of 10 females. The results represent the average ( \pm standard deviation) of the 5 groups tested. Averages in the same column, which are followed by different letters, differ statistically among each other, according to the Kruskal-Wallis test $(\mathrm{P}<0.05)$.

\begin{tabular}{cccc}
\hline $\begin{array}{c}\text { Quantity of yeast in diet } \\
(\mathrm{g})\end{array}$ & $\begin{array}{c}\text { Number of } \\
\text { eggs/female/day }\end{array}$ & $\begin{array}{c}\text { Ingestion } \\
(\mathrm{mg} / \mathrm{female} / \text { day })\end{array}$ & Diet Efficiency \\
\hline 0 & $0 \mathrm{a}$ & $1.06 \pm 0.78 \mathrm{a}$ & $0 \mathrm{a}$ \\
1.0 & $0 \mathrm{a}$ & $1.14 \pm 0.64 \mathrm{a}$ & $0 \mathrm{a}$ \\
2.5 & $0.01 \pm 1.06 \mathrm{a}$ & $1.25 \pm 0.57 \mathrm{a}$ & $0 \mathrm{a}$ \\
4.5 & $0.43 \pm 13.47 \mathrm{ab}$ & $1.72 \pm 0.70 \mathrm{~b}$ & $0.24 \pm 0.06 \mathrm{ab}$ \\
6.5 & $1.00 \pm 23.55 \mathrm{~b}$ & $1.84 \pm 0.79 \mathrm{~b}$ & $0.56 \pm 0.17 \mathrm{~b}$ \\
\hline
\end{tabular}

Table II. Performance in A. obliqua females fed on diets with different quantities of yeast, during 18 days. Each group consisted initially of 10 females. The results represent the average ( \pm standard deviation) of the 6 pairs tested. Averages in the same column, which are followed by different letters, differ statistically among each other, according to the Mann Whitney test $(\mathrm{P}<0.05)$. The experiments were carried out and analyzed in pairs of groups (frame by frame).

\begin{tabular}{cccc}
\hline $\begin{array}{c}\text { Quantity of yeast in } \\
\text { diet }(\mathrm{g})\end{array}$ & $\begin{array}{c}\text { Number of } \\
\text { eggs/female/day }\end{array}$ & Ingestion & $\begin{array}{c}\text { Diet Efficiency } \\
\text { (mg/female/day) }\end{array}$ \\
\hline 6.5 & $0.33 \pm 8.44 \mathrm{a}$ & $1.54 \pm 1.18 \mathrm{a}$ & $0.21 \pm 0.11 \mathrm{a}$ \\
8.5 & $0.88 \pm 16.27 \mathrm{~b}$ & $1.61 \pm 0.65 \mathrm{a}$ & $0.56 \pm 0.13 \mathrm{~b}$ \\
\hline 8.5 & $0.88 \pm 16.27 \mathrm{a}$ & $1.61 \pm 0.65 \mathrm{a}$ & $0.56 \pm 0.13 \mathrm{a}$ \\
10.5 & $1.84 \pm 22.7 \mathrm{~b}$ & $1.83 \pm 0.53 \mathrm{~b}$ & $1.00 \pm 0.36 \mathrm{~b}$ \\
\hline 10.5 & $1.24 \pm 22.6 \mathrm{a}$ & $2.34 \pm 1.63 \mathrm{a}$ & $0.53 \pm 0.25 \mathrm{a}$ \\
12.5 & $2.80 \pm 35.87 \mathrm{~b}$ & $2.39 \pm 1.24 \mathrm{a}$ & $1.21 \pm 0.47 \mathrm{~b}$ \\
\hline 12.5 & $1.13 \pm 27.99 \mathrm{a}$ & $2.89 \pm 2.38 \mathrm{a}$ & $0.43 \pm 0.28 \mathrm{a}$ \\
14.5 & $2.32 \pm 42.7 \mathrm{a}$ & $3.02 \pm 4.54 \mathrm{a}$ & $0.80 \pm 0.60 \mathrm{a}$ \\
\hline 14.5 & $0.34 \pm 14.34 \mathrm{a}$ & $2.30 \pm 1.39 \mathrm{a}$ & $0.10 \pm 0.18 \mathrm{a}$ \\
16.5 & $0.23 \pm 9.05 \mathrm{a}$ & $3.51 \pm 2.22 \mathrm{~b}$ & $0.05 \pm 0.08 \mathrm{a}$ \\
\hline 16.5 & $0.75 \pm 26.78 \mathrm{a}$ & $1.74 \pm 1.64 \mathrm{a}$ & $0.64 \pm 0.75 \mathrm{a}$ \\
18.5 & $0.38 \pm 12.95 \mathrm{a}$ & $2.29 \pm 2.28 \mathrm{a}$ & $0.13 \pm 0.22 \mathrm{a}$ \\
\hline
\end{tabular}

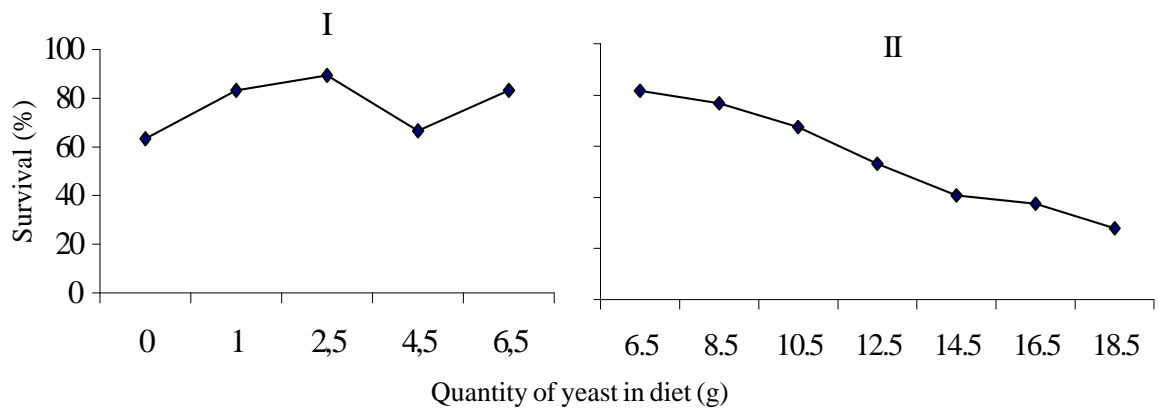

Fig. 1. Survival (\%) of A. obliqua females fed on diets containing different quantities of protein during 18 days experimentation period, for experiment I and II. The results represent the average of the groups. Each group consisted initially of 10 females. In I, there was no statistical difference between the groups. In II, statistical differences occurred only with the $6.5 \mathrm{~g}$ diet in relation to the $16.5 \mathrm{~g}$ and $18.5 \mathrm{~g}$. 
Mann-Whitney test, but for the survival results which were analyzed through the KruskalWallis test, at a significance level of 5\%.

As it had happened with experiment I, the ingestion rates increased with the yeast concentration, in such a way that no compensatory response was observed (tab. II). There were statistical differences in ingestion rates for the diets with $8.5 \mathrm{~g}$ and $10.5 \mathrm{~g}$, and for the diets with $14.5 \mathrm{~g}$ and $16.5 \mathrm{~g}$. Egg production increased with ingestion up to $14.5 \mathrm{~g}$ of yeast in diet, whereas it fell with the higher quantities. There were statistical differences for this parameter for the diets containing $6.5 \mathrm{~g}$ and $8.5 \mathrm{~g}, 8.5 \mathrm{~g}$ and $10.5 \mathrm{~g}$, $10.5 \mathrm{~g}$ and $12.5 \mathrm{~g}$. If only egg production had been considered, the $14.5 \mathrm{~g}$ yeast diet could be considered the optimal concentration for A. obliqua, although no statistical difference was observed for this diet in relation to the $12.5 \mathrm{~g}$ diet. It can be seen that survival does not confirm that fact, since it clearly fell as yeast concentration rose (fig. 1), and $6.5 \mathrm{~g}$ was the quantity that yielded the highest survival rate (81.7\%). According to the calculation of diet efficiency, which relates the number of eggs produced to the diet ingestion, the $12.5 \mathrm{~g}$ yeast diet was the quantity considered optimal for A. obliqua, although survival rate was of $53.3 \%$. Despite this difference in survival rate, the statistic results were only different in the: $6.5 \mathrm{~g}$ and $16.5 \mathrm{~g}, 6.5 \mathrm{~g}$ and $18.5 \mathrm{~g}$, and 8.5 and $18.5 \mathrm{~g}$ diets, what shows that $12.5 \mathrm{~g}$ of yeast can be considered the best quantity in a diet, since it yielded both average egg production and average survival. The $14.5 \mathrm{~g}$ yeast diet yielded a higher egg production than the one resulting from consumption of the $12.5 \mathrm{~g}$ diet; however, survival was much lower and tended to fall even more with higher yeast concentrations. This would disqualify those yeast concentrations, since survival was measured during the first 18 days of adult life, a period when there was still no oviposition, which generally begins around the 18th day.

\section{DISCUSSION}

Although individuals from the genus Anastrepha (Schiner, 1868) show an admirable plasticity in behaviors such as, feeding, rest and oviposition, (AlUJA \& BIRKE, 1993), the females need an exogenous protein source for egg production, which should be ingested in an optimal quantity. Below and above this quantity reduction of performance can occur (SAVOPOULOU-SOULTANI et al., 1994). Experiments performed with varied protein sources to A. obliqua showed that $7.0 \mathrm{~g}$ of yeast promoted the highest egg production (Message \& Zucoloto, 1989). It is interesting that quantities higher than $7.0 \mathrm{~g}$ of yeast caused damageable effects on egg production. However, quantities higher than that were used in the present study and positive results were obtained, what disagrees with Message \& Zucoloto (1989) data. These differences can be explained by the different season in which the experiments were performed. The wild females are exposed to environmental variations that can cause a strong selective pressure. Along the time the population can present behavioral and physiological changes. Another plausible explanation would be the difference in the yeast batches. According to Cangussu \& Zucoloto (1995), different yeast batches can have quantitative and qualitative differences in the nutrient contents causing differences on the performance.

In the present work, the results from Experiment I did not correspond to the expected: females did not ingest more from the less quantity of yeast diet to compensate the nutritive deficiency of that element, as it occurred with C. capitata, (CANGussu \& 
Zucoloto, 1992). On the contrary, females ingested more of the diet with a higher quantity of yeast; in this way, they neither showed any compensatory response, nor it was possible to verify the optimal yeast quantity in the diet for $A$. obliqua. If the insect ingests a nutrient quantity higher than the optimal for its species, its digestive system will not adapt itself to the high osmolarity of the solution (DADD, 1985). This will reduce the insect performance, as demonstrated in C. capitata fed on diets that had different concentrations of a mixture of aminoacids. Egg production fell with diet concentrations higher than the optimal (1.2g) (FERRO \& ZuCOLOTO, 1990). In the present study it was observed that, for diets with $0.0 \mathrm{~g}, 1.0 \mathrm{~g}$ and $2.5 \mathrm{~g}$ of yeast, egg production was null, what indicates that the quantities used in those diets were below the optimal for A. obliqua. Because this species has no protein storage from the larval stage, egg production did not occur. For diets with yeast concentrations higher than $14.5 \mathrm{~g}$, egg production fell and survival became critical, since it was below $50 \%$ in a period during which oviposition had not started yet. Although these harmful and even lethal effects may occur, some adaptations exist to lessen them as, for instance, an increase of enzymatic activity or accumulation of substance (LEMOS et al., 1992) or other kinds of post-ingestion compensatory responses.

There are other works with A. obliqua adults that used a mixture of aminoacids similar to the casein composition, or even with casein itself, and the quantities found as optimal were much lower than the results obtained here: $2.4 \mathrm{~g}$ (BRAGA \& Zucoloto, 1981) and 4.8g (FERRO \& ZuCOLOTO, 1989). Those diets contained other nutrients besides those used in the present work, such as salts, lipids and vitamins, what might influence the utilization of the protein source and the egg production. Tsiropoulos (1980) documented that vitamins, minerals and other nutrients present in many protein sources may be important for a normal production of healthy eggs, although it has been demonstrated more recently that, for C. capitata, the amount of salt and vitamins required for egg production depends, essentially, on the type of diet ingested by the larvae (CANATO et al., 1994).

Contrary to the results found by CANGussu \& Zucoloto (1992) for C. capitata, using brewer yeast in different concentrations, in the present study the highest ingestion rate was observed to occur in the diet containing the highest protein quantity $(18.5 \mathrm{~g})$. This kind of non-compensatory response does not agree with the other studies that showed that the concentration of nutrients in the hemolymph may regulate the quantity of food to be ingested (Bernays, 1985; Abisgold \& Simpson, 1988; Simpson et al., 1991; Simpson \& Raubenheimer, 1993). Feeding on high protein diets, the $A$. obliqua females should have high aminoacid levels in the hemolymph and, according to that mechanism, should decrease the consumption. There is, still, the possibility that other haemolymph factors limit the quantity of food, such as osmotic pressure and the volumetric factor. The effect of hemolymph osmotic pressure is relatively small when compared to volumetric factors. According to BERNAYs (1985) the abdominal feedback may be the most important factor in protein ingestion regulation. Results obtained with Rhagoletis pomonella (Walsh), fed on liquid diets, support this volumetric hypothesis (HeNDRICHS et al., 1993).

Food ingestion is also regulated by its physical nature. Hardness and resistance are food parameters of particular relevance. There are examples of some species varieties for which food hardness has reduced feeding or increased time spent in ingestion 
(BERNAYs, 1985). The non compensation with solid diets may also be related to metabolic costs involved in their utilization (JACOME et al., 1995), since the energy obtained from this kind of food does not compensate the energy spent in its ingestion and digestion; in the same way, it is not compensatory for the individual to ingest great quantities of low protein diets: the energy consumption for ingestion and digestion of small quantities of highly concentrated diets is the same as for large amounts of diets with low concentration. HENDRICHS et al. (1993) have also found that $R$. pomonella fed on solid diets liquefy the food with salivary secretion. Metabolic water, which is used to produce saliva, is chiefly obtained by catabolism of lipid reserves, what involves consumption of energy. Besides that extra consumption of energy, a considerable cleaning of mouth pieces during rest periods between feeding events is necessary, thus increasing energy consumption (HENDRICHS et al., 1993).

One explanation for the high ingestion of diets with greater yeast content is that the protein source, in this case the yeast, works as a phagostimulant. Apparently, the sugar present in food works as a feeding stimulus for flies, although there is the possibility of stimulation by other chemical compounds or by the synergy between sugar and other food constituents (BERNAYS, 1985). In the most phytophagous insects it is common to select different nutrients, normally present in their host plants, to work as phagostimulants (BERNAYs, 1985). It is possible that $A$. obliqua use protein compounds as phagostimulants because of their dependence on this nutrient for egg production. VANDERZANT (1974) found that both wheat germ and brewer's yeast are rich in important nutrients for the insects, besides containing substances apparently attractive to the species. SHARP \& Chambers (1984) found that several aminoacids, many of which are present in yeast, are high phagostimulants for both $A$. suspensa males and females, and are, apparently, the active compounds responsible for the amounts of protein ingested by the flies. Phagostimulant effectiveness is measured in different species as the ingested quantity during one feeding event, or during a period of time, and increases up to a maximum concentration, above which the ingested quantities can be reduced (BERNAYs, 1985).

Fruit flies have specific hunger and behavioral responses for protein and carbohydrate sources (LANDOLT \& DAVIS-HERNANDEZ, 1993). These behavioral responses are, very often, more specific for aminoacids and protein compounds than for sugars (Hsiao, 1985), maybe because sugars are found in nature in higher abundance than protein sources.

In relation to performance, it is relevant for the species that females produce the greatest possible number of eggs. The highest survival rate verified with the $6.5 \mathrm{~g}$ yeast diet may indicate a tendency to a greater longevity, what would be equally favorable in terms of performance as the time of egg production would be longer. The experiment was performed during pre-oviposition period, where the concentration of $14.5 \mathrm{~g}$ of yeast provided the highest egg production. The number of eggs in the abdomen does not represent the whole size of a progeny, because oviposition had not occurred: the females had died before oviposition began and, even if oviposition had occurred, the short longevity would not have allowed a higher egg production. According to diet efficiency, the $12.5 \mathrm{~g}$ yeast diet proved to be the optimal quantity in relation to egg production as the amounts ingested were smaller, for the same number of eggs produced. Longevity of A. obliqua females fed on $6.5 \mathrm{~g}$ of sucrose can last more than 60 days, with an average egg production. It is indisputable that survival is an important parameter concerning 
egg production, when considering that the number of eggs produced in the first 18 days of adult life does not represent the total reproductive potential of $A$. obliqua throughout its life span. The diet with $12.5 \mathrm{~g}$ of yeast can be considered the optimal quantity of yeast to A. obliqua, because it promotes the best survival and egg production. Quantities above that may be considered harmful. Quantities between $6.5 \mathrm{~g}$ and $12.5 \mathrm{~g}$ may, in general, be considered good for the maintenance of A. obliqua flies in laboratory, depending on the perspective of the study to be conducted.

\section{REFERENCES}

Abisgold, J. D. \& Simpson, S. J. 1987. The Physiology of compensation by locusts for changes in dietary protein. J. exp. Biol., London, 129:329-346.

. 1988. The effect of diet protein levels and haemolymph composition on the sensitivity of the maxillary palp chemoreceptors of locust. J. exp. Biol., London, 135:215-219.

Aluja, M. 1994. Bionomics and management of Anastrepha. A. Rev. Ent., Palo Alto, 39:155-178.

Aluja, M. \& BiRKe, A. 1993. Habitat use by adults of Anastrepha obliqua (Diptera, Tephritidae) in a mixed mango and tropical plum Orchard. Ann. ent. Soc. Am., Lanham, 86(6):799-812.

Bernays, E. A. 1985. Regulation of feeding behaviour. In: Kerkut, S. A. \& Gilbert, L. I. ed. Comprehensive Insect Physiology, Biochemistry Pharmacology, Oxford, Pergamon. v. 5, p.390-467.

BRAGA, M. I. S. \& ZuCOLOTo, F. S. 1981. Estudos sobre a melhor concentração de aminoácidos para moscas adultas de Anastrepha obliqua (Diptera, Tephritidae). Revta bras. Biol., Rio de Janeiro, 41(1):75-79.

Canato, C. M.; Fernandes-Da-Silva, P. G. et al. 1994. Influência de sais e vitaminas na produção de óvulos por Ceratitis capitata (Wiedemann, 1824) (Diptera: Tephritidae). Científica, São Paulo, 22(1):15-20.

Cangussu, J.A. \& Zucoloto, F. S. 1992. Nutritional value and selection of different diets by adult Ceratitis capitata flies (Diptera: Tephritidae). J. Insect Physiol., Oxford, 38(7):485-491.

—. 1995. Self-selection and perception threshold in adults females of Ceratitis capitata (Diptera, Tephritidae). J. Insect Physiol., Oxford, 41(3):223-227.

Dadd, R. H. 1985. Nutrition: organisms. In: Kerkut, S. A. \& Gilbert, L. I. ed. Comprehensive Insect Physiology, Biochemistry Pharmacology, Oxford, Pergamon. v. 4, p. 313-390.

Ferro, M. I. T. \& Zucoloto, F. S. 1989. Efeito do Balanço de Proteína e Carboidrato na Dieta de Anastrepha obliqua Macquart, 1835 (Diptera: Tephritidae). Científica, São Paulo, 17(1): 1-5.

- 1990. Effect of the quantity of dietary aminoacids on egg production and layings by Ceratitis capitata (Diptera, Tephritidae). Brazilian J. Med. Biol. Res., Ribeirão Preto, 23:525-531.

Fontellas, T. M. L. \& Zucoloto, F. S. 1999. Nutritive value of diets with different carbohydrates for adult Anastrepha obliqua (Macquart) (Diptera, Tephritidae). Revta bras. Zool., Curitiba, 16: 1135-1147.

Hamilton, R. L. \& Schal, C. 1988. Effects of dietary protein levels on reproduction and food consumption in the German cockroach (Dyctioptera: Blatellidae). Ann. ent. Soc. Am., Lanham, 81(6):969-976.

Hendrichs, J.; Fletcher, B. S. \& ProKopy, R. J. 1993. Feeding behavior of Rhagoletis pomonella flies (Diptera: Tephritidae): effect of initial food quality and quantity on food foraging, handling cost and bubbling. J. Insect Behaviour, New York, 1 (6):43-64.

Hsiao, T. H. 1985. Feeding behavior. In: Kerkut, S. A. \& Gilbert, L. I. ed. Comprehensive Insect Physiology, Biochemistry Pharmacology, Oxford, Pergamon. v. 6, p. 471-512.

JACOME, I.; Aluja, M. et al. 1995. The influence of adult diet and age on lipid reserves in the Tropical fruit fly Anastrepha serpentina (Diptera: Tephritidae). J. Insect Physiol., Oxford, 41(12):1079-1086.

Landolt, P. J. \& Davis-Hernandez, K. M. 1993. Temporal patterns of feeding by Caribbean fruit flies (Diptera: Tephritidae) on sucrose and hidrolyzed yeast. Ann. ent. Soc. Am., Lanham, 86(6):749-755.

Lemos, F. J. A.; Zucoloto, F. S. \& TerRa, W. R. 1992. Enzymological and excretory adaptations of Ceratitis capitata (Diptera: Tephritidae) larvae to high protein and high salt diets. Comp. Biochem. Physiol., Oxford, 102A(4):775-779.

Message, C. M. \& Zucoloto, F. S. 1989. Effect of some artificial diets on egg production by Anastrepha obliqua (Diptera, Tephritidae). Revta bras. Biol., Rio de Janeiro, 49(3):699-701.

Savopoulou-Soultani, M.; Stavridis, D. G. et al. 1994. Response of Lobesia botrana (Lepidoptera: Tortricidae) to levels of sugar and protein in artificial diets. J. Econ. Entomol., 87(1):84-90.

SharP, J. L. \& ChAmbers, D. L. 1984. Consumption of carbohydrates and amino acids by Anastrepha suspensa (Loew)(Diptera: Tephritidae) in the laboratory. Envir. Ent., Lanham, 13(3):768-773. 
Simpson, S. J. \& ABISGoLd, J. D. 1985. Compensation by locusts for changes in dietary nutrients: behavioral mechanisms. Physiol. Ent., Oxford, 10:443-452.

Simpson, S. J.; Barton-Browne, L. \& VAn Gerwen, A. C. M. 1989. The patterning of compensatory sugar feeding in the australian sheep blowfly. Physiol. Ent., Oxford, 14:91-105.

Simpson, S. J.; Simmonds, M. S. J. \& Blaney, W. M. 1991. Variation in chemosensitivity and the control of dietary selection behavior in the locust. Appetite, London, 17:141-154.

Simpson, S. J. \& Raubenheimer, D. 1993. The Central role of the haemolymph in the regulation of nutrient intake in insects. Physiol. Ent., Oxford, 18:395-403.

Tsiropoulos, G. J. 1980. Carbohydrate utilization by normal and gamma-sterilised Dacus oleae. J. Insect Physiol., Oxford, 26:633-637.

VANDERZANT, E. S. 1974. Development, significance and application of artificial diets for insects. A. Rev. ent., Palo Alto, 19:139-160.

Zucoloto, F. S.; Puschel, S. \& Message, C. M. 1979. Valor nutritivo de algumas dietas artificiais para Anastrepha obliqua. Bolm Zool. Univ. S. Paulo, São Paulo, 4:75-80.

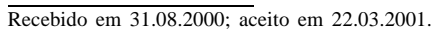

Iheringia, Sér. Zool., Porto Alegre, (91): 53-60, 27 de novembro de 2001 